\title{
Once Again Why Lexicography Is Science*
}

\author{
Tinatin Margalitadze, Lexicographic Centre, Ivane Javakhishvili Tbilisi \\ State University, Tbilisi, Georgia (tinatin.margalitadze@tsu.ge)
}

Lexicography is a scientific practice aiming to bring dictionaries into existence ${ }^{1}$ Franz Josef Hausmann

\begin{abstract}
The article addresses some issues connected with the disciplinary status of lexicography. Drawing on the views of scholars such as L. Zgusta, R. Ilson, H. Wiegand, R. Gouws, H. Bergenholtz, S. Tarp, R. Lew and others, the author argues in favour of the viewpoint that lexicography is a science and that working on a dictionary is a scientific activity. The main issues tackled in the paper include understanding the complex nature of word meaning, the role of dictionaries in the description of word meaning and the development of lexical semantics. Attention is also paid to the definitional method of the study of word meaning, which is based on the analysis of dictionary definitions, components of the theory of lexicography, the relation between lexicographic theory and practice, and the teaching of lexicography as an academic discipline at universities.

The author argues that the right approach to lexicography and its disciplinary status is particularly important in our era of globalisation. Only state-of-the-art lexicographic and corpus resources will secure the future of many languages, particularly lesser-used languages, and such resources will not be created until lexicography receives proper recognition as a science with "big interdisciplinary vocation" (Tarp 2017); until lexicography is turned into an academic discipline through advanced theory of lexicography, through teaching lexicography at universities, etc.
\end{abstract}

Keywords: DISCIPLINARY STATUS OF LEXICOGRAPHY, MEANING OF WORDS, COMPONENTIAL ANALYSIS OF MEANING, DEFINITIONAL METHOD OF ANALYSIS, OED, THEORY OF LEXICOGRAPHY, LEXICOGRAPHIC PRACTICE, TEACHING LEXICOGRAPHY, ACADEMIC DISCIPLINE, MA IN LEXICOGRAPHY

Opsomming: Nog eens waarom leksikografie 'n wetenskap is. In hierdie artikel word ' $n$ paar kwessies met betrekking tot die vakstatus van leksikografie aangespreek. Gebaseer op die sienings van vakkundiges soos L. Zgusta, R. Ilson, H. Wiegand, R. Gouws, H. Bergenholtz, $\mathrm{S}$. Tarp, R. Lew en ander, argumenteer die outeur ten gunste van die siening dat die leksikografie ' $\mathrm{n}$ wetenskap is en dat die samestelling van 'n woordeboek 'n wetenskaplike aktiwiteit is. Die hoofkwessies wat in hierdie artikel aangespreek word, sluit die komplekse aard van woordbetekenis, die rol van woordeboeke in die beskrywing van woordbetekenis en die ontwikkeling van die leksi-

* This article is a revised version of a paper presented as keynote address at the Twentysecond Annual International Conference of the African Association for Lexicography (AFRILEX), hosted by the School of Languages and Literatures: African Language Studies Section, Rhodes University, Grahamstown, South Africa, 26-29 June 2017. 
kale semantiek in. Daar word ook aandag geskenk aan die definisiële studiemetode van woordbetekenis, wat gebaseer is op die ontleding van woordeboekdefinisies, komponente van die leksikografieteorie, die verband tussen die leksikografiese teorie en -praktyk, en die onderrig van die leksikografie as 'n akademiese dissipline by universiteite.

Die outeur argumenteer dat die korrekte benadering tot die leksikografie en die vakstatus daarvan besonder belangrik in hierdie era van globalisering is. Slegs die heel nuutste leksikografiese en korpushulpbronne sal die toekoms van baie tale, spesifiek minder gebruikte tale, verseker, en voor hierdie hulpbronne geskep kan word, moet die leksikografie behoorlike erkenning as ' $n$ wetenskap met "('n) groot interdissiplinêre taak" (Tarp 2017) geniet; moet gevorderde leksikografieteorie in 'n akademiese vakrigting verander word, moet leksikografie aan universiteite onderrig word, ens.

Sleutelwoorde: VAKSTATUS VAN LEKSIKOGRAFIE, BETEKENIS VAN WOORDE, KOMPONENSIËLE BETEKENISANALISE, DEFINISIËLE ANALISEMETODE, OED, LEKSIKOGRAFIETEORIE, LEKSIKOGRAFIESE PRAKTYK, DIE ONDERRIG VAN LEKSIKOGRAFIE, AKADEMIESE DISSIPLINE, MA IN LEKSIKOGRAFIE

\section{Introduction}

In 1747 Samuel Johnson writes in his famous work The Plan of a Dictionary of the English Language:

WHEN first I undertook to write an English Dictionary ... I knew that the work in which I engaged is generally considered as drudgery for the blind, as the proper toil of artless industry; a task that requires neither the light of learning, nor the activity of genius, but may be successfully performed without any higher quality than that of bearing burdens with dull patience, and beating the track of the alphabet with sluggish resolution. Whether this opinion, so long transmitted, and so widely propagated, had its beginning from truth and nature, or from accident and prejudice; whether it be decreed by the authority of reason or the tyranny of ignorance, that, of all the candidates for literary praise, the unhappy lexicographer holds the lowest place. (Johnson, in Practical Lexicography, 2008)

In the 21st century, some lexicographers in some countries still experience the same underappreciation of their work. Below I quote from an Appeal of Georgian Lexicographers to the Georgian Government and the Academic Community, adopted at the First International Symposium in Lexicography in Batumi (May 2010):

The present status of Georgian lexicography, which has a long history and rich heritage of tradition and experience, gives ground for serious concern. Regrettably, the colossal toil of lexicographers remains almost totally unappreciated in present-day Georgia, namely:

- The result of lexicographic work is not classed among scientific categories in general and in process of present-day contests and rating assessments in particular; 
- Lexicographic work and its product are not yet entitled to the right of being competitive participants of modern grant competitions;

- Salaries of lexicographers are inadequate, compelling them to earn livelihood by means of other activities;

- Lexicographers are not awarded academic (scientific) degrees for the lexicographic products they create". ${ }^{2}$

It is probably worth mentioning here that Oxford University rewarded Samuel Johnson with a Master of Arts degree after the publication of his Dictionary in 1755 (he had studied only one year at Oxford, which he had to leave for financial reasons).

In July 2010, the text of the above-mentioned Appeal was forwarded to the Organising Committee of the XIV International Symposium of EURALEX (European Association for Lexicography), held in Leeuwarden, the Netherlands. Georgian lexicographers requested their European colleagues to discuss the Appeal of Georgian lexicographers and express their viewpoints concerning the issues raised in it. The Board of EURALEX agreed to add their voices to the Appeal.

"Within academia, lexicography is frequently overlooked, relegated to being a mere craft rather than an academic discipline. Such a notion is misguided and dangerous. Lexicographers not only study language for what it is, the central tool for communication, but also provide the means by which a language, and its underlying cultural values, may be taught and given full value within a society", wrote then president of EURALEX, Professor Geoffrey Williams in his letter addressed to the Georgian Government and the Academic Community $^{3}$ (Williams 2016).

During the last couple of years the board of EURALEX has sent several such letters to colleagues from different countries to support their lexicographic projects or their campaigns for the rights of lexicographers.

The XVII EURALEX International Congress, held in Tbilisi, Georgia in September 2016 (http://euralex2016.tsu.ge) adopted a resolution addressed to UNESCO, national governments throughout the world, research funding agencies, and universities to acknowledge the status of lexicography as an academic discipline and promote the study of words and languages. 'Our multilingual world needs novel types of dictionaries, which requires proper recognition and support', states the resolution. ${ }^{4}$

Prior to the adoption of the resolution, a round-table discussion was organised within the framework of the congress which was dedicated to the status of lexicography. 'One of the hot topics today is whether lexicography should be seen merely as a "craft", or as a scientific academic discipline whose theory should be taught in universities, like mainstream linguistics', stated the synopsis of the discussion. ${ }^{5}$

These statements reveal that in the 21st century we may still come across 
opinions that working on a dictionary is not a scientific activity. Such views are very damaging to lexicography and hinder its proper development.

Lexicography, which has a centuries-old history, has undergone significant evolution. Glosses, glossaries and dictionaries of hard words were replaced by dictionaries which incorporated the whole vocabulary of each particular language. Methods of description and study of word meaning also underwent drastic changes. Corpora of thousands of illustrative phrases and sentences from the works of literature emerged as the main tool of the study of meaning, paving the way for the development of scholarly lexicography. Lexicography has always kept abreast of the newest developments in linguistics and related sciences, frequently even being ahead of these developments. The advent of comparative-historical linguistics was reflected in the entries of the Oxford English Dictionary on Historical Principles (OED). The development of electronic corpora and corpus linguistics in the 1980s was also immediately reflected in lexicography, as the study of word meaning since then has been entirely based on the analysis of vast corpus data. The appearance of electronic dictionaries has opened completely new prospects for lexicography turning it into one of the most dynamic and rapidly developing fields of knowledge. Modern lexicography is a complex, multidisciplinary field incorporating multiple components, viz. semantic theories, corpus-based methods, methods and techniques for natural language processing, e-lexicography, research on dictionary use, dictionary criticism, dictionary didactics, terminology, etymology and so on. Consequently, claims that working on a dictionary does not constitute a scientific activity seem to be an unbelievable misunderstanding.

Some scholars such as Ladislav Zgusta (1971, 1992/93), Herbert Wiegand (1984), Robert Ilson (2012), Rufus Gouws (2012), Henning Bergenholtz (2012), Sven Tarp (2017), Robert Lew (2007) and others have published interesting articles on the status of lexicography. This is how Robert Ilson explains the lack of understanding of what lexicography really is:

Between them, the academics, professional lexicographers, and computerniks provided a round view of lexicography as a whole. The problem was, however, that each group had on its own a limited view of the subject. The academics had their Ideas; the computerniks, their Algorithms. But too often, alas, they seemed to lack detailed knowledge of what dictionaries are actually like and how dictionaries are actually produced. On the other hand, the professional lexicographers seemed often to lack detailed knowledge of linguistics; and their superbly detailed knowledge of Really Existing Dictionaries seemed often to be limited to those they had actually worked on ... but lexicographers have scant time or incentive to contribute to learned journals: after all, they have dictionary deadlines to meet. (Ilson 2012)

In his article "Lexicography as an Independent Science", Sven Tarp (2017) gives an interesting classification of different viewpoints on the disciplinary status of 
lexicography, himself advocating the view that lexicography is "a science with its own independent core and a big interdisciplinary vocation" and that it should be treated as "an independent discipline with its own theory, own tasks and own methods". The independent disciplinary status of lexicography is also supported by H. Bergenholtz, R. Gouws (Bergenholtz and Gouws 2012), T. Bothma and D. Prinsloo (Bothma et al. 2016).

In this article I also want to formulate my viewpoints on this issue as a practical lexicographer with the experience of working on general and terminological dictionaries (Comprehensive English-Georgian Dictionary (CEGD), EnglishGeorgian Military Online Dictionary (EGMD), English-Georgian Biology Online Dictionary (EGBD), English-Russian-Georgian Technical Online Dictionary (ERGTD)), as a scholar who has studied different theoretical aspects of lexicography and as a lecturer who teaches lexicography at all three university levels.

\section{Understanding the Complex Nature of Word Meaning}

From my personal observation, one of the reasons for the above-mentioned simplistic attitude towards lexicography, stating that it is not a science, stems from the superficial approach to the intricate phenomenon of meaning and related issues.

"As you surely know, one of the many surprising facts about the discipline of linguistics in the 20th century was that the study of lexis and meaning was largely neglected in America, Britain, and their spheres of influence. Honourable exceptions were in the European Saussurean tradition - notably German semantic field theorists such as Trier, Porzig, and Weisgerber and the Romanian Eugene Coseriu; British Firthians such as Halliday and Sinclair, Russians such as Mel'cuk and Apresjan, and others. But these past researchers were hampered by, among other things, lack of evidence and the political crises of their time", writes Patrick Hanks in the new proposal of the University of Wolverhampton "Studying meaning in the 21st century".

One of the reasons may be traced back to descriptive linguistics, which treated the lexical level of language as peripheral and non-structural for decades, concentrating on the description of phonological and morphological systems of language.

After being the philologists' prime object of investigation in the nineteenth century, the lexicon had been neglected in favour of syntax and phonology, as it was more difficult to describe and encapsulate it in rules. Vocabulary was deemed the least significant part of a language by the structuralists. Some of them even doubted that vocabulary was a part of a language. Ullmann in his Semantics also confirms that semantics was mostly formal the first three-quarters of the twentieth century and that lexicology was hardly regarded as a branch of linguistics. ${ }^{6}$ 
This approach to the phenomenon of meaning was also reflected in the methodology of componential analysis which drew its inspiration from structural phonology and like distinctive phonological features, the combination of which describes each phoneme, tried to describe meaning on the basis of a restricted set of semantic components (Geeraerts 2010: 70-80). It is genuinely surprising for me how one could believe that it was possible to describe meaning the same way as a phoneme with a finite set of features.

The complex nature of meaning is determined by the complexity of the cognition of the world with which it is closely connected. Cognition of the world is a multi-step, multifaceted process of perception, generalisation, formation of concepts, etc. A word is not only the main nominative but also the main cognitive unit of a language and its lexical meaning is determined by the reflection of some segment of extralinguistic reality, i.e. a class of things, events, etc. (denotatum) in our minds, in the mind of a language community. Meaning is a concept (designatum) attached to a word. Lexical meaning reflects not a segment of reality (denotatum) but the concept (designatum) that a language community has about it. The world around us is infinite, therefore describing meaning with a finite number of features and formalising it the same way as phonology or syntax was doomed to failure, but such views discouraged its study. As a consequence, if the scientific study of meaning was impossible, then lexicography, which was primarily involved in the study of words and their meanings, could not be a science. Later, this disregard for the content plane of language changed, and nowadays different theories of lexical semantics study meaning from many different angles (Geeraerts 2010), but it has left its mark on the understanding of the essence of lexicography.

The above-mentioned approach to the study of meaning is even more surprising as the dictionaries which emerged in the 19th and 20th centuries provided excellent scientific studies of meaning reflected in their word entries. The proof of this is one of the methods of componential analysis of meaning applied by Georgian linguists (following the tradition of Soviet linguistics), the so-called definitional method of analysis (Margalitadze 2014). The school of linguistics at Tbilisi State University (mostly English philologists) following theories of some Russian (e.g. V.G. Gak) and foreign linguists (e.g. American E. Nida) viewed meaning as a structure consisting of semantic components arranged in a hierarchical order. The Georgian linguist Mary Iankoshvili (1972) regarded the meaning of a word as a structure consisting of a core and peripheral potential semes. According to her theory, the core consists of a grammatical categorial semantic component (form which expresses meaning), a lexical categorial (hyponymic) semantic component and a differential seme or semes. Potential semes are arranged around the core; they reflect different features of denotatum described by the meaning of a word which is characteristic of denotatum or is ascribed to it by a language community. In other words, the core corresponds to the archisemes and differential semes of V.G. Gak; archilexemes and distinctive semes in the terminology of Pottier; or the common and diagnostic 
semes of E. Nida. In general, these theories of word meaning distinguished archisemes or hyponymic semantic components, differential semantic components and potential or supplementary semantic components. Traditional lexicographic practice of the second half of the 19th century (OED and its European counterparts) regarded word meaning the same way and defined words in an analytical way by splitting them up into more basic semantic components, Distinctive-Feature Semantics, in other words. This methodology of defining meaning in the 19th century dictionaries follows the tradition of Aristotelian and Thomistic philosophy, which is known as a definition 'per genus proximum et differentias specificas'. The above-mentioned dictionaries described not only hyponymic and differential features of meaning. They also paid a lot of attention to the description of supplementary features of meaning, different potential semes which served as the basis for the development of tranferred meanings of polysemous words, and were the basis of metaphor, metonymy and other mechanisms of semantic change.

To illustrate: the OED, while defining the word father, alongside lexical categorial (hyponymic) and differential semantic components (a kinship term, nearest male ancestor), provides numerous supplementary components: a male ancestor more remote than a parent, esp. the founder of a race or family, a forefather, progenitor (definition 2); one who institutes, originates, calls into being (definition 3.a); one who exercises protecting care like that of a father; one who shows paternal kindness; one to whom filial reverence and obedience are due (definition 4.a); applied to God, expressing His relation to Jesus, to mankind in general (considered either as His offspring, as the objects of His loving care, or as owing Him obedience and reverence), or to Christians (as His children by regeneration or adoption) (definition 5.a), etc. (see Figure 1).

In the entry for heart, the OED describes not only the hyponymic component of its meaning - the bodily organ, or the differential semantic component The hollow muscular or otherwise contractile organ which, by its dilatation and contraction, keeps up the circulation of the blood in the vascular system of an animal (definition 1.a) - but various definitions of the entry reveal different supplementary semantic components ascribed to the concept of heart by the English language community: the seat of life (definition 2); the seat of one's inmost thoughts and secret feelings (definition 6.a); the seat of emotions (definition 9.a); the seat of love or affection (definition 10.a); the seat of the mental or intellectual faculties (definition 12), the seat of courage (definition 11.a), etc. As reported by South African colleagues, the seat of courage in some African languages is the liver and not the heart. Interestingly, heart surgeons would argue that the heart is not the seat of anything, but just a pump. It is exactly the existence of these potential semantic components, different features associated with the same object of reality in different languages, that makes the study of meaning worthwhile and interesting. 


\begin{tabular}{|l|l|l|l|}
\hline Oxford English Dictionary \\
\hline Dictionary Advanced Search Results History Bookmarks Options l Help Home \\
\hline father|
\end{tabular}

Figure 1: Entry of father from the OED

Hanks (2000) argues that the meaning potential of each word is made up of a number of components. These components may be activated cognitively by other words in the context in which they are used and are linked in a network which forms the semantic base of the language. This holds enormous dynamic potential for saying new things and relating the unknown to the known.

Thus the meaning of each word is unique, it consists of a unique combination of semantic components, therefore the meaning of each word is to be analysed individually. As Zgusta justly stresses in his Manual of Lexicography, what lexicographers have at their disposal is utterances, concrete instances of the usage of a word in a particular context. On the basis of the study of utterances, lexicographers deduce meaning or meanings of a word. Lexicographers of the 17th-18th centuries knew this quite well. Samuel Johnson collected 250000 quotations from 500 sources for his dictionary. The 19th century lexicographers developed this method further and the OED team was able to collect 10 million quotation slips to be analysed for their dictionary.

Did lexicographers know what meaning was or how to describe it? Undoubtedly they knew it very well, they created and used corpora for their 
research and they described word meaning in a way that transformed dictionaries into the main tools of study of meaning in the following decades.

Dictionaries of the 18th and 19th centuries did not use semantic theories to describe meaning, as there were none, but they created these theories through each word-entry and gave impetus to the development of lexical semantics.

As mentioned above, the method which was developed to study the semantic structure of a word and its semantic components was called the definitional method of analysis, which is based on the comparison and analysis of definitions of comprehensive explanatory dictionaries. Especially noteworthy in this regard are the Oxford English Dictionary on Historical Principles (OED) and Webster's Third New International Dictionary, whose definitions had become the basic source for the semantic study of English words before the advent of corpus linguistics and its methods.

The growth of the Internet in recent decades, the introduction of corpora as well as corpus linguistics have provided unprecedented opportunities for more objective studying of and research into language and meaning; however, it is not the case that meaning was not studied in previous decades.

\section{Theory of Lexicography and its Components}

Another reason for not regarding lexicography as a science is the view that lexicography has no theory. I fully agree with Gouws (Gouws 2012) that the authority of some European scholars who voice these claims is partly responsible for such views.

In 1983, at the founding congress of EURALEX, the German linguist Herbert Wiegand (Wiegand 1984) formulated the structure and components of metalexicography: 1 . History of lexicography; 2 . General theory of lexicography; 3 . Research on dictionary use; 4 . Criticism of dictionaries. theories:

The general theory of lexicography is subdivided into 4 constituent
A. General Section;
B. Theory of organisation;
C. Theory of lexicographical research on language;
D. Theory of the lexicographical description of language.

In the general section, Wiegand singles out three components: 1. Purposes of Dictionaries; 2. Relationship to other theories; 3 . Principles from the history of lexicography.

Theory B is concerned with the organisation of labour in the three fields of activity.

Theory C comprises three components: 1 . Data collection; 2. Data processing; 3. Computer assistance. In theory D two components are distin- 
guished: 1 . Dictionary typology; 2 . Textual theory for lexicographical texts (i.e. the structure of lexicographical texts).

This was an excellent starting point for the development of a unified theory of lexicography and a unified understanding of its components, which has not happened. Defining the scope of lexicographic theory is important, otherwise many theoretical issues will not be sufficiently researched and treated in scientific literature. The study of the theoretical issues is important in the transitional period from printed to online media and particularly at present, when lexicography is at the crossroads of new developments in the era of the Internet and modern technologies.

From my point of view, a theory of lexicography accumulates and develops the knowledge necessary for lexicographers in dictionary production and is made up of the following components:

\section{General lexicographic theory}

This part of the lexicographic theory comprises the essence and functions of lexicography, dictionary typology, different theories necessary for dictionary production, i.e. theories of lexical semantics, methods of semantic research, including methods of corpus linguistics, theory and methods of natural language processing, etc.

\section{History of Lexicography}

\section{Genres of Lexicography}

This part of lexicographic theory includes a description of the lexicographic principles underlying different genres of lexicography: comprehensive monolingual dictionaries; comprehensive bilingual dictionaries; monolingual, bilingual and multilingual learner's dictionaries; historical dictionaries; terminological dictionaries; specialised dictionaries and so on. This section also comprises electronic lexicography and the changes it has brought about in the actual production of dictionaries. Genres of lexicography study the methodology of planning different stages of dictionary production, selection of sources, data collection and processing, producing entries for different types of dictionaries and modern technologies used in the production of different types of dictionaries. I view criticism of dictionaries in this section, as criticism of different types of dictionaries should be based on the knowledge of the genres.

\section{Research on Dictionary Use}

What is practical lexicography? How is the production of dictionaries connected to the theory?

From our experience, the actual production of dictionaries is not simply the application of theory to practice. The knowledge of the theory of lexicography and its components described above is the basis for lexicographers while planning and implementing their dictionary project. Practical work on a dictionary starts with: 
1. The plan of a dictionary, detailed description of the principles that the dictionary will be based on, principles of selection of lemmas, treatment of homonyms, multiword units, etc.; description of the sources, principles of data collection and data processing, etc. For this work lexicographers need the theoretical knowledge mentioned above, knowledge of the target group and their needs and preferences, research on dictionary use and knowledge of other studies and experiments in the field. While planning a dictionary, lexicographers need knowledge of the history of the development of the same type of dictionaries, specificities of the genre, etc. Thus, at the very start, while planning their dictionaries, lexicographers need knowledge of the theory: of the history, of the genre specificities and so on.

2. The second stage is data collection for the dictionary. At this stage lexicographers need the knowledge of general lexicographic theory, theories of lexical semantics, methods of the study of meaning, etc. They also need knowledge of data collection and data processing experience in the genre and so on.

3. The actual compilation of entries is by no means an activity where lexicographers do not need theory. Each entry is unique with a unique meaning which a lexicographer needs to investigate on the basis of the sources and data collected. For each entry, a lexicographer goes through the stages of data collection, data processing, checking sources, deducing meanings, selecting illustrative material, studying connotation of the meaning and range of application and so on and so on (Zgusta 1971).

Theory and practice of lexicography do not exist independently of each other; it is not a ready theory which is uncritically applied in practice. Knowledge of theory is necessary for practical work and practical work is not simply compilation but work based on sound theoretical knowledge and the study of each unique meaning, undertaken by knowledgeable lexicographer-scholars. Each lexicographic project enriches the theory of lexicography with new solutions discovered by lexicographers working on different projects. Lexicographers may need to develop completely new principles for the creation of some dictionaries, but they still need to know the existing best practices to find better solutions for their projects.

"What is called the theory of lexicography is not something opposed to lexicographic practice, nor is it an endeavor that largely coincides with linguistics (theoretical or otherwise)" (Zgusta 1992/93: 137). Robert Lew (2007: 212) understands metalexicography as the "theoretical foundation to lexicographic practice".

What can be deduced from the above? Is working on a dictionary a "craft"? We strongly believe that it is a scientific activity rather than a "craft". We believe that only the highly competent, broadly educated lexicographers can work on the creation of dictionaries. The work of such a scholar is creative and intellectual and in its process it is impossible to make a distinction between its 
general theoretical and current applied aspects. Consequently, we find the interpretation of lexicography expressed in the following phrase by Franz Josef Hausmann, a prominent German lexicographer and lexicographic theoretician more acceptable: "Lexicography is a scientific practice aiming to bring dictionaries into existence". We think that such an approach is more correct and adequate, giving a better idea of the essence of the subject (Meladze 2016).

\section{Should the Theory of Lexicography Be Taught?}

"One of the hot topics today is whether lexicography should be seen merely as a 'craft', or as a scientific academic discipline whose theory should be taught in universities, like mainstream linguistics". This is a statement from the synopsis of the Round Table Discussion at Tbilisi Congress in September 2016.

At the founding congress of EURALEX in 1983, mentioned earlier, the British scholar John Sinclair (Sinclair 1984) raised the issue of setting up a master's course in lexicography which would contribute to transforming lexicography from a practical activity into an academic discipline and would develop lexicography in close relation with information technologies, computer linguistics, general linguistics and lexicographic practice.

While developing the curriculum for the MA programme in lexicography at Tbilisi State University, we took into consideration the above-mentioned views, as well as our understanding of the theory of lexicography and its components. The programme comprises the following courses: word meaning and methods of its research; main genres of lexicography; history of lexicography; introduction to corpus linguistics and corpus-based lexicography; theories of lexical semantics; practical courses in general and specialised lexicography and so on.

We fully agree with John Sinclair that it is the unity of theory and practice that turns lexicography into an academic discipline, and with Sven Tarp (2017) that "lexicographical practice can be transformed into a 'scientific activity' when it is guided by an advanced theory (provided this theory is lexicographical)".

\section{The Georgian Case}

As mentioned in the introduction, views that working on a dictionary is not a scientific activity are very damaging to lexicography and hinder its proper development. The adverse results of underappreciation of lexicography can be well seen by the observation of processes taking place in my native language, Georgian.

Lexicography was a well-developed field of knowledge in Georgia and people involved in lexicographic work were respected by the academic community, as well as by Georgian society. The Comprehensive English-Georgian Dictionary was a research project of the Department of English Philology for 
more than 30 years and when we started the publication of the Dictionary on a letter-by-letter basis in the 1990s, the presentation of the first fascicle, the letter A, was attended by the intellectual elite of Tbilisi of that time.

This attitude started to deteriorate after the break-up of the Soviet Union and the consequent period of political turmoil. Within ten to fifteen years, interest in lexicography started to decline and this short period proved to be enough to have grave consequences for Georgian lexicography. As referred to earlier, the Appeal of Georgian Lexicographers to the Georgian Government and the Academic Community (May, 2010) stated, the status of Georgian lexicography gave ground for serious concern. The appeal expressed their regret that the colossal toil of lexicographers remained almost totally unappreciated in Georgia.

Such circumstances eventually led to a shortage of qualified lexicographers working in the field, a shortage of academic dictionaries, the cessation of terminological work, deterioration of knowledge of foreign languages and quality of translations, etc. One more consequence was the decline of interest in published dictionaries and their application in teaching foreign languages. These processes were further aggravated by new methods for teaching foreign languages. These methods spread to the schools and higher-education institutions of Georgia greatly diminished the role of translation and reduced the practice of using the native language in the process of teaching foreign languages. This naturally led to the elimination of the use of bilingual/translation dictionaries, with an accompanying shift toward the use of explanatory, i.e. monolingual dictionaries (Margalitadze and Meladze 2016). From the same period of decline the Georgian language has been exposed to the comprehensive influence of the English language: the Internet and modern information and communications technologies; growing international contacts as a result of the years of regained independence; the free market economy, new entrepreneurial and legal relations; revolutionary advancements almost in every field of science and technology were linked with the formation of new concepts, with new terms which have naturally inundated Georgian directly via English. Unnecessary loans from English started to flood the vocabulary of Georgian, gradually taking the form of an avalanche, engulfing dozens of Georgian words on a daily

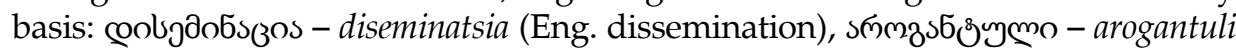

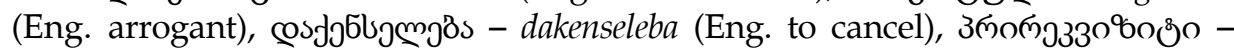

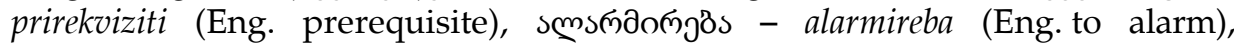

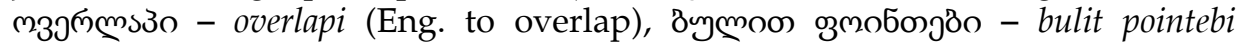
(Eng. bullet points), Зธฮீ cited loans have equivalents in Georgian, sometimes even several equivalents. These tendencies were even more alarming in terminology. New terms, even multi-word terms, were introduced into the Georgian language mainly by means of transliteration: З

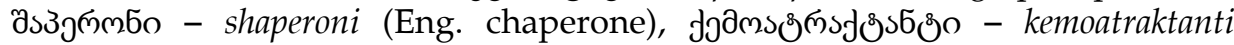

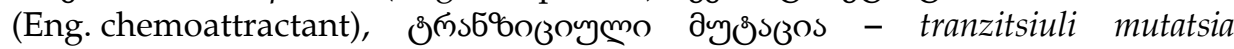

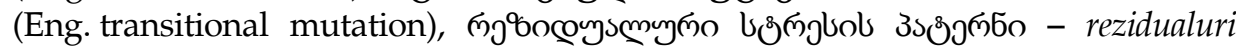


stresis paterni (Eng. residual stress pattern) and so on. Our recent study has revealed that $90 \%$ of terms are introduced into Georgian as transliterated forms of the corresponding English terms. The number of such loans is so extensive that it already hinders communication in society and is a constant source of irritation to the Georgian public. Georgian lexicography should have served as a filter for this situation; the dictionaries should have protected Georgian from chaotic processes and professional lexicographers should have investigated different strategies for introducing emerging new concepts into the lexis of Georgian. During this period it was necessary to compose and publish new English-Georgian terminological dictionaries, to compose new EuropeanGeorgian type dictionaries and to intensify the work on the new edition of the Explanatory Dictionary of the Georgian Language. It was necessary to revise existing dictionaries, to compose Georgian corpora and terminological databases, to develop language technologies for the Georgian language and so on. Instead, lexicography in Georgia was in a critical state.

The struggle for saving Georgian lexicography started in 2010, with the first symposium in lexicography. The appeal of Georgian lexicographers and the support letter of EURALEX helped to develop a more positive attitude towards lexicography in Georgia. The most important achievement was the setting up of a committee for the enhancement of lexicography in Georgia at the Ministry of Education and Science of Georgia. The Committee is working on a National Programme in Lexicography. MA and PhD programmes in Lexicography were launched at Tbilisi State University, but the damage done to the language and terminology is so great that it will take years of hard work and dedication to mitigate these consequences and to produce a new generation of dictionaries for the Georgian language.

\section{Conclusion}

From our observation, the viewpoint that working on a dictionary is not a scientific activity is determined by a lack of understanding of the complex nature of word meaning as well as the complexity of its description. The complex nature of meaning is determined by the complexity of the cognition of the world with which it is closely connected. Another reason for such an approach to lexicography is the opinion that lexicography has no theory. Such views hinder the proper understanding of lexicography as a complex, multidisciplinary field incorporating multiple components. From our point of view, the theory of lexicography accumulates and develops the knowledge necessary for lexicographers in dictionary production and is made up of the following components: general lexicographic theory, history of lexicography, genres of lexicography and research on dictionary use. A dictionary is created according to a well-prepared model which is based on a sound theoretical approach. It is the unity of theory and practice that turns lexicography into an academic discipline. 
This paper also discussed the Georgian case in order to highlight how the neglect of lexicography in Georgia during the last 10-15 years has led to the deterioration of the State language of Georgia.

The right approach to lexicography and its disciplinary status is particularly important in our era of globalisation. Only state-of-the-art lexicographic and corpus resources will secure the future of many languages, particularly lesser-used languages. Such resources will not be created until lexicography receives proper recognition as a science with "big interdisciplinary vocation" (Tarp 2017). These resources will not be created until the realisation that dictionaries are "great cultural vehicles", repositories of our languages, so vital for the preservation of our national identities. The creation of such resources is not cheap, but governments and societies should realise that this is an investment in the preservation of our languages and cultures, an investment in the democracy of our multilingual world.

\section{Endnotes}

1. Hausmann, F.J. (1985)

2. The full text of the appeal is available at the following URL: http://blog.dictionary.ge/ en/archives/114.

3. The full text of the EURALEX letter is available at the following URL: http://blog.dictionary. ge/en/archives/134.

4. The full text of the Resolution of the XVII EURALEX International Congress (September 2016) is available at the following URL: http://euralex.org/resolution2016/.

5. The recording of the Round Table discussion is available at the following URL: http://euralex2016.tsu.ge/media.html.

6. Quoted from: Henri Béjoint's The Lexicography of English, p. 264.

\section{References}

Béjoint, H. 2010. The Lexicography of English. Oxford: Oxford University Press.

Bergenholtz, H. and R.H. Gouws. 2012. What is Lexicography? Lexikos 22: 31-42.

Bothma, T.J.D., R.H. Gouws and D.J. Prinsloo. 2016. The Role of e-Lexicography in the Confirmation of Lexicography as an Independent and Multidisciplinary Field. Margalitadze, T. and G. Meladze (Eds.). 2016. Proceedings of the XVII EURALEX International Congress. Lexicography and Linguistic Diversity, Ivane Javakhishvili Tbilisi State University, Tbilisi, Georgia, 6-10 September, 2016: 109-116. Tbilisi: Ivane Javakhishvili Tbilisi State University. Available at: http://euralex. org/category/publications/euralex-2016/.

(CEGD) Margalitadze, T. (Editor-in-chief), G. Meladze, A. Chanturia et al. 1995-2012. Comprehensive English-Georgian Dictionary (Vol. I-XIV); the Online Version www.dict.ge. Tbilisi: Ivane Javakhishvili Tbilisi State University, Lexicographic Centre.

(EGBD) Khundadze, G., G. Meladze, T. Margalitadze et al. (Eds.). 2014. English-Georgian Biology Online Dictionary. http://bio.dict.ge. Tbilisi: Ivane Javakhishvili Tbilisi State University, Lexicographic Centre. 
(EGMD) Khundadze, G., G. Meladze, T. Margalitadze et al. (Eds.). 2010. English-Georgian Military Online Dictionary. http://mil.dict.ge. Tbilisi: Ivane Javakhishvili Tbilisi State University, Lexicographic Centre.

(ERGTD) Khundadze, G., G. Meladze, T. Margalitadze et al. (Eds.). 2016. English-Russian-Georgian Technical Online Dictionary. http://techdict.ge. Tbilisi: Ivane Javakhishvili Tbilisi State University, Lexicographic Centre.

Gak, V.G. 1977. Comparative Lexicology. Moscow: International Relations (In Russian).

Geeraerts, D. 2010. Theories of Lexical Semantics. New York: Oxford University Press.

Gouws, R.H. 2012. Theoretical Lexicography and the International Journal of Lexicography. International Journal of Lexicography 25(4): 450-463.

Hanks, P. 2000. Do Word Meanings Exist? Computers and the Humanities 34: 205-215.

Hausmann, F.J. 1985. Lexikographie. Schwarze, Christoph and Dieter Wunderlich (Eds.). 1985. Handbuch der Lexikologie: 367-411. Königstein/Ts.: Athenäum.

Iankoshvili, M. 1972. Core Structure of Word Meaning. Foreign Languages at School 3: 3-11 (In Georgian).

Ilson, R. 2012. IJL: The First Ten Years - And Beyond. International Journal of Lexicography 25(4): 381-385.

Johnson, S. 1747. The Plan of a Dictionary of the English Language. Fontenelle, Thierry (Ed.). 2008. Practical Lexicography: A Reader: 19-30. Oxford/New York: Oxford University Press.

Lew, R. 2007. Linguistic Semantics and Lexicography: A Troubled Relationship. Fabiszak, M. (Ed.). 2007. Language and Meaning. Cognitive and Functional Perpectives: 217-224. Frankfurt am Main: Peter Lang.

Margalitadze, T. 2014. Polysemous Models of Words and Their Representation in a Dictionary Entry. Abel, A., C. Vettori and N. Ralli. (Eds.). 2014. Proceedings of the XVI EURALEX International Congress: The User in Focus, EURALEX 2014, Bolzano/Bozen, Italy, July 15-19, 2014: 1025-1037. Bolzano/Bozen: Institute for Specialised Communication and Multilingualism. Available at: http://euralex.org/category/publications/euralex-2014/.

Margalitadze, T. and G. Meladze. 2016. Importance of the Issue of Partial Equivalence for Bilingual Lexicography and Language Teaching. Margalitadze, T. and G. Meladze (Eds.). 2016. Proceedings of the XVII EURALEX International Congress: Lexicography and Linguistic Diversity, Ivane Javakhishvili Tbilisi State University, Tbilisi, Georgia, 6-10 September, 2016: 787-797. Tbilisi: Ivane Javakhishvili Tbilisi State University. Available at: http://euralex.org/category/ publications/ euralex-2016/.

Meladze, G. 2016. Towards the Scientific Status of Lexicography. Spekali 10. Electronic Bilingual Scholarly Journal. Tbilisi: Ivane javakhishvili Tbilisi State University. Available at http:// www.spekali.tsu.ge/index.php/en/article/viewArticle/10/99/.

Nida, E.A. 1975. Componential Analysis of Meaning. The Hague/Paris: Mouton.

(OED) Oxford English Dictionary on Historical Principles. (Vol. I-XIII; suppl. I-IV). Oxford: Oxford University Press.

Sinclair, J. 1984. Lexicography as an Academic Subject. Hartmann, R.R.K. (Ed.). 1984. LEXeter '83 Proceedings. Papers from the International Conference on Lexicography at Exeter, 9-12 September 1983: 13-30. Tübingen: Max Niemeyer.

Tarp, S. 2017. Lexicography as an Independent Science. Fuertes-Olivera, Pedro A. (Ed.). 2017. The Routledge Handbook of Lexicography: 19-33. London: Routledge. 
Wiegand, H.E. 1984. On the Structure and Contents of a General Theory of Lexicography. Hartmann, R.R.K. (Ed.). 1984. LEXeter '83 Proceedings. Papers from the International Conference on Lexicography at Exeter, 9-12 September 1983: 13-30. Tübingen: Max Niemeyer.

Williams, G. 2016. In Praise of Lexicography, and Lexicographers. Margalitadze, T. and G. Meladze (Eds.). 2016. Proceedings of the XVII EURALEX International Congress: Lexicography and Linguistic Diversity, Ivane Javakhishvili Tbilisi State University, Tbilisi, Georgia, 6-10 September, 2016: 77-88. Tbilisi: Ivane Javakhishvili Tbilisi State University. Available at http://euralex.org/category/ publications/euralex-2016/.

Zgusta, L. 1971. Manual of Lexicography. Prague: Academia / The Hague: Mouton.

Zgusta, L. 1992/93. Lexicography, Its Theory, and Linguistics. Dictionaries 14: 130-138. 